\title{
PENGARUH ONLINE CUSTOMER REVIEW DAN ONLINE CUSTOMER RATING TERHADAP KEPERCAYAAN KONSUMEN REMAJA KOTA MATARAM PADA PEMBELIAN PRODUK FASHION SHOPEE ONLINE SHOP
}

\author{
Taesar Wahyudi*) \\ Baiq Handayani $R^{* *}$ \\ Sulaeman Sarmo ${ }^{* *}$
}

\begin{abstract}
This study aims to prove and analyze the effect of online customer reviews, online customer ratings on customer trust in online shopping at Shopee. This type of research is correlational research because this study aims to study the differences between two or more variables. The data collection method used is a survey method. The population in this study is the teenagers of the city of Mataram who bought 10-24 years who had bought fashion products online at Shopee. Purposive sampling technique, with a total sample of 120. The distribution of questionnaires using the form of goggles. The data analysis tool used is Multiple Linear Regression Analysis using the SPSS 22 program for Windows. The results of this study indicate that online customer reviews and online customer ratings have a significant positive effect on customer trust
\end{abstract}

Keywords : Online Customer Review, Online Customer Rating, Customer Trust.

\section{Pendahuluan}

Pada era globalisasi dan kemunculan internet membuuat para pengusaha kecil, menengah maupun besar memanfaatkan media internet dalam memajukan usaha bisnisnya atau yang sering disebut sebagai e-commerce. Dalam dunia e-commerce barang yang diperjual belikan tentunya beragam, namun berdasarkan data yang bersumber dari statistik.kominfo.go.id menyatakan bahwa produk fashion merupakan produk yang paling sering dibeli dengan presentase sebesar $73,80 \%$. Berdasarkan penelitian pendahuluan yang dilakukan dengan menyebarkan kuesioner melalui google forms, Didapati bahwa produk fashion merupakan produk yang paling sering dibeli oleh remaja di kota Mataram dengan presentase sebesar $72,7 \%$.

Saat ini begitu banyak market place yang menjual produk fashion termasuk Shopee. Berbelanja secara online di Shopee tentu memberikan berbagai macam pilihan produk fashion namun disisi lain konsumen memiliki sedikit informasi berkaitan dengan produk atau toko onlinenya. Sehingga hal yang perlu diperhatikan dalam berbelanja online adalah mengenai kepercayaan konsumen. Kepercayaan merupakan suatu pondasi dalam sebuah proses bisnis. Suatu transaksi antara dua pihak atau lebih akan terjadi apabila kedua belah pihak saling mempercayai.

Arif Pitoyo dalam laporannya yang berjudul Rakuten Smart Shopping Survey juga menemukan $78 \%$ pembeli online kecewa pada produk belanjaannya. Mayoritas memilih hanya berselancar dan mencari produk online, tapi sering akhirnya batal membeli lantaran tak jelas apakah penjual atau produknya dapat dipercaya, begitu juga saat mendapati harganya terlalu mahal. Karena dalam belanja online antara penjual dan pembeli tidak

\footnotetext{
*Fakultas Ekonomi dan Bisnis Unram, email : tesarwahyudi1@gmail.com

${ }^{* *}$ Fakultas Ekonomi dan Bisnis Unram
} 
bertemu secara langsungg dan tidak kenal satu sama lain. Selain itu konsumen juga tidak bisa memeriksa kondisi dari atribut produk yang diinginkan.

Adanya resiko transaksi pembelian secara online menyebabkan calon konsumen melakukan berbagai macam cara untuk menyakinkan diri mereka dalam membeli produk secara online, salah satunya dengan mencari informasi-informasi yang berkaitan dengan atribut produk atau toko online. Untuk memudahkan calon konsumene mendapatkan informasi, menyediakan dua fitur yaitu online customer review dan online customer rating. Melalui kedua fitur ini diharapkan konsumen mendapatkan informasi berkaitan dengan kualitas dari produk ataupun kualitas pelayanan yang diberikan toko online, meskipun dari orang yang tidak dikenal dan diharapkan pula mempengaruhi kepercayaan konsumen terhadap market place maupun produk yang ditawarkan.

Ahmad Farki (2016) menyatakan bahwa fitur utama yang ada pada online marketplace saat ini adalah penggunaan review dan rating sebagai tools untuk meningkatkan minat maupun kepercayaan pelanggan. Berdasarkan survey terhadap 5000 pembelanja dari lima negara berbeda, mengindikasikan online rating dan review pada retail website menjadi sumber informasi yang paling sering diakses.

Berdasarkan uraian diatas perlu dilakukan penelitian yang berjudul Pengaruh Online Customer Review Dan Online Customer Rating Terhadap Kepercayaan Konsumen Remaja Kota Mataram Pada Pembelian Produk Fashion Shopee Online Shop.

\subsection{Rumusan Masalah}

1. Apakah terdapat pengaruh online customer review terhadap kepercayaan konsumen dalam berbelanja produk fashion secara online di Shopee?

2. Apakah terdapat pengaruh online customer rating terhadap kepercayaan konsumen dalam berbelanja produk fashion secara online di Shopee?

\subsection{Tujuan Penelitian}

1. Untuk mengetahui pengaruh online customer review terhadap kepercayaan konsumen dalam berbelanjaproduk fashion secara online di Shopee.

2. Untuk mengetahui pengaruh online customer rating terhadap kepercayaan konsumen dalam berbelanjaproduk fashion secara online di Shopee.

\section{Kerangka Teoritis}

\subsection{Online Customer Review}

Online customer review (OCR), sebagai salah satu tipe dari electronic word-of- mouth (eWOM), menyediakan informasi mengenai produk dan rekomendasi dari perspektif konsumen (Lee et al., 2008). OCR menjadi hal yang penting bagi konsumen dalam melakukan pembelian online. Menurut Filieri, (2014) online customer review (OCR) adalah salah satu bentuk word of mouth communication pada penjualan online, dimana calon pembeli mendapatkan informasi tentang produk dari konsumen yang telah mendapatkan manfaat dari produk tersebut. Konsumen bila kesulitan menduga kualitas dari suatu produk atau jika dugaan kriteria dari produk adalah ambigu, maka adanya informasi menjadi salah satu penentu dalam membuat keputusan.

Saat berbelanja online, konsumen menghadapi banyak pilihan, disisi yang lain konsumen hanya memiliki sedikit informasi langsung dengan produk karena konsumen tidak dapat menyentuh atau merasakan produk. Untuk mengatasi kelemahan ini, maka dibuat OCR yang menyediakan informasi yang relevan kepada konsumen (Chou, 2012), dikatakan relevan karena OCR dilakukan secara sukarela oleh konsumen yang telah membeli produk tersebut. Ahmad Farki (2016) menyatakan bahwa fitur utama yang ada pada online marketplace saat ini adalah penggunaan review dan rating sebagai tools untuk meningkatkan minat maupun kepercayaan pelanggan. 


\subsection{Online Customer Rating}

Rating merupakan suatu hal yang sama dengan review namun opini yang diberikan oleh konsumen dalam bentuk skala yang ditentukan. Sebuah skema peringkat popular untuk rating di toko online adalah dengan memberikan bintang. Semakin banyak memberikan bintang, maka menunjukkan peringkat penjual yang semakin baik (Lackermair et al., 2013). Rating dibuat oleh konsumen yang telah melakukan pembelian secara online dan dipublikasikan didalam website atau lapak dari penjual.

Pemeringkatan atau rating dalam produk secara online menjadi salah satu cara konsumen berpendapat tentang kualitas produk online, meskipun terkadang ada bias yang terjadi dalam pengukurannya, hal ini terutama disebabkan oleh penilaian produk oleh konsumen yang mencerminkan kepuasan konsumen secara global, tidak hanya pada produknya saja, tetapi juga pada bagaimana konsumen dilayani oleh penjual online (Engler et al., 2015). Selain itu, permasalahan lainnya adalah konsumen tidak menjelaskan kualitas produk yang seharusnya dinilainya.

\section{Pengembangan Hipotesis}

$\mathrm{H} 1$ = Diduga bahwa online customer review berpengaruh signifikan terhadap kepercayaan.

$\mathrm{H} 2$ = Diduga bahwa online customer rating berpengaruh signifikan terhadap kepercayaan.

\section{Metode Penelitian}

\subsection{Jenis Penelitian}

Jenis penelitian yang digunakan dalam penelitian ini adalah penelitian kuantitatif. Dilihat dari sifat permasalahannya penelitian ini termasuk penelitian korelasional. Penelitian korelasional ini untuk mengetahui tingkat hubungan antara dua variabel tanpa melakukan perubahan, tambahan atau manipulasi terhadap data yang sudah ada (Arikunto, 2013). Dalam penelitian ini ingin membuktikan pengaruh online customer review dan online customer rating terhadap kepercayaan pembelian produk fashion di Shopee.

\subsection{Sumber Data}

Sumber data yang digunakan dalam penelitian ini adalah data primer dan data sekunder.

\subsection{Metode Pengumpulan Data}

Metode pengumpulan data yang digunakan dalam penelitian ini adalah metode survei. penelitian survei adalah penelitian yang mengambil satu populasi dan menggunakan kuesioner sebagai alat pengumpulan data yang pokok.

\subsection{Alat Pengumpulan Data}

Alat pengumpulan data yang digunakan dalam penelitian ini adalah kuesioner yang berupa sejumlah pertanyaan tertulis untuk memeroleh informasi dari responden dalam arti laporan tentang pribadinya atau hal-hal yang diketahuinya.

\subsection{Waktu dan Lokasi Penelitian}

Waktu penelitian pada tanggal 25 Februari 2019. Lokasi penelitian dilakukan di wilayah kota Mataram. Peneliti memilih lokasi ini karena remaja di wilayah Mataram cenderung dalam belanja online produk yang sering dibeli adalah produk fashion. 


\subsection{Populasi Penelitian}

Menurut Sugiyono (2009), populasi adalah wilayah generalisasi yang terdiri atas objek dan subjek penelitian yang mempunyai kualitas dan karakteristik tertentu yang ditetapkan oleh peneliti untuk dipelajari dan kemudian ditarik kesimpulannya. Populasi dari penelitian ini adalah remaja kota mataram yang berusia 10-24 tahun yang melakukan pembelian produk fashion di shopee.

\subsection{Sampel Penelitian}

Sampel yang digunakan dalam penelitian ini adalah noprobability sampling. Menurut Sugiyono (2009) nonprobability sampling adalah teknik yang tidak memberi peluang/kesempatan yang sama bagi setiap unsur atau anggota populasi untuk dipilih menjadi sampel Teknik pengambilan sampel dengan purposive sampling atau pengambilan sampel berdasarkan kriteria tertentu seperti :

1. Responden memiliki aplikasi atau akses ke situs Shopee.

2. Pernah melakukan pembelian minimal sekali melalui situs atau aplikasi Shopee.

3. Waktu pembelian minimal 1 tahun terakhir.

4. Mengetahui online customer review dan online customer rating.

Jumlah sampel yang diambil dalam penelitian ini menggunakan rumus Lemeshow, hal ini dikarenakan jumlah populasi tidah diketahui atau tidak terhingga. Berikut rumus Lameshow yaitu :

$\mathrm{n}=\frac{\mathrm{z} 1-\mathrm{a} / 2 \mathrm{P}(1-\mathrm{P})}{\mathrm{d}^{2}}$

Keterangan :

$n=$ Jumlah sampel

$z=$ skor $z$ pada kepercayaan $95 \%=1,96 p=$ maksimal estimasi $=0,5$

$d=$ alpha $(0,10)$ atau sampling error $=10 \%$

Melalui rumus di atas, maka jumlah sampel yang akan diambil adalah :

$n=\frac{z^{2} 1-\alpha / 2 P(1-P)}{d^{2}}$

$\mathrm{n}=\frac{1,962^{2} \cdot 0,5(1-0,5)}{0,1^{2}}$

$\mathrm{n}=\underline{3,8416 \cdot 0.25}$

$\mathrm{n}=96,04=100$

Sehingga jika berdasarkan rumus tersebut maka $n$ yang didapatkan adalah 96,04 = 100 orang sehingga pada penelitian ini setidaknya penulis harus mengambil data dari sampel sekurang - kurangnya sejumlah 100 orang.

\section{Analisis Data}

Solusi pemecahan permasalahan penelitian ini dilakukan dengan analisis Regresi berganda dengan bantuan SPSS 22 yang diawali dengan uji asumsi klasik. Dari hasil uji asumsi klasik menunjukan bahwa, data yang diperoleh memenuhi asumsi normalitas, multikolinearitas, sehingga dapat dilanjutkan dengan analisis Regresi Linear Berganda. 


\subsection{Analisis Regresi Linier Berganda}

Hasil dari analisis regresi linier berganda bisa dilihat di bawah ini : Tabel. Hasil Analisis Regresi Linier Berganda

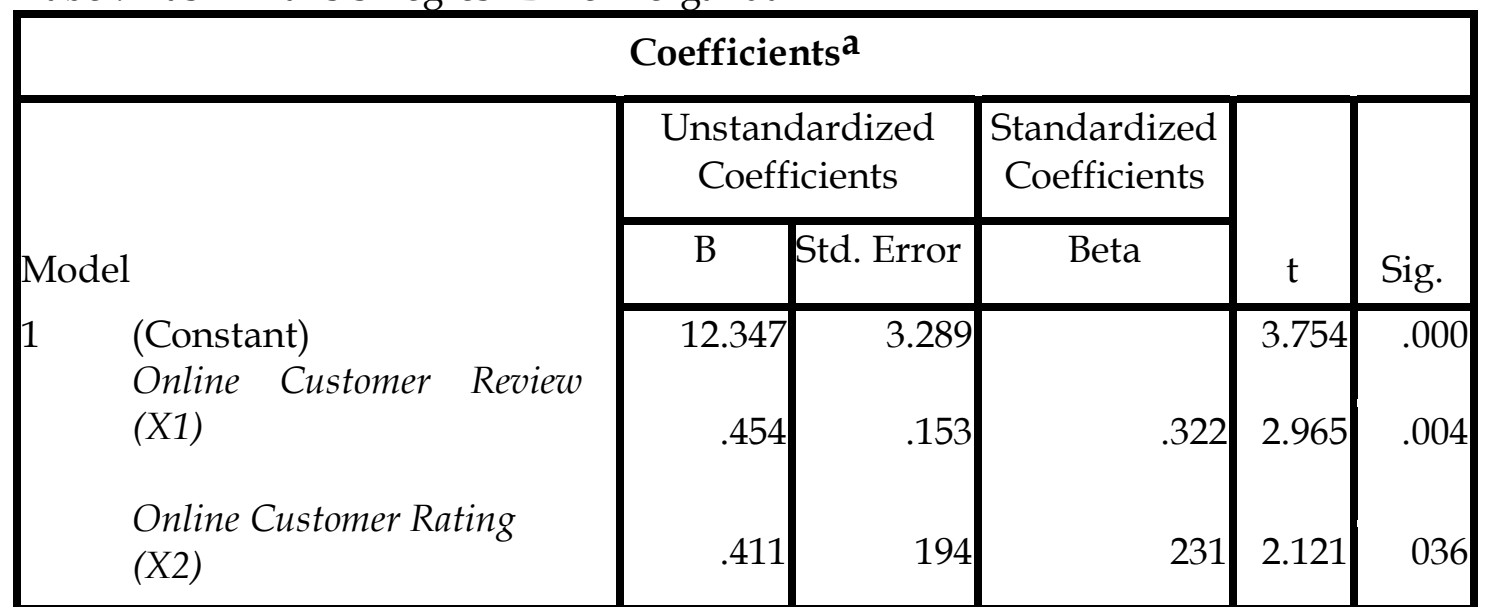

Output SPSS, data diolah, 2019

Bedasarkan tabel di atas dapat disusun persamaan regresi linier bergandanya, yaitu:

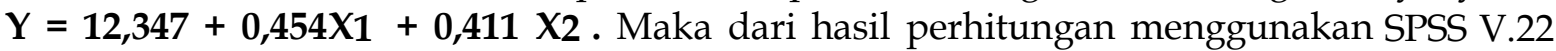
pada tabel di atas dapat interpretasikan sebagai berikut:

Pengaruh variabel online customer review (X1) terhadap kepercayaan $(\mathrm{Y})$, berdasarkan perbandingan nilai thitung dengan nilai ttabel dan perbandingan nilai signifikansi, menunjukan thitung $(2.965)>$ ttabel $(1,980)$ dan nilai signifikansi variabel online customer review sebesar $(0,004)<$ taraf sig 0,05 , yang berarti bahwa H0 ditolak dan Ha diterima. Dengan demikian hipotesis pertama (H1) online customer review (X1) berpengaruh positif signifikan terhadap kepercayaan $(\mathrm{Y})$.

Pengaruh variabel online customer rating $(\mathrm{X} 1)$ terhadap kepercayaan $(\mathrm{Y})$, berdasarkan perbandingan nilai thitung dengan nilai ttabel dan perbandingan nilai signifikansi. Maka berdasarkan tabel 4.11 diketahui nilai thitung $(2.121)>$ tabel $(1,980)$ dan nilai signifikansi variabel online customer rating sebesar $(0,036)<$ taraf sig 0,05 , yang berarti bahwa $\mathrm{H} 0$ ditolak dan Ha diterima. Dengan demikian hipotesis kedua (H2) online customer rating (X2) berpengaruh signifikan terhadap kepercayaan (Y).

\section{Pembahasan}

\subsection{Pengaruh Online Customer Review Terhadap Kepercayaan}

Hipotesis yang menyatakan bahwa "online customer review berpengaruh signifikan terhadap kepercayaan remaja Kota Mataram dalam membeli produk fashion di Shopee" Terbukti. Berdasarkan pengamatan peneliti sebelum calon konsumen membeli produk fashion di Shopee, calon konsumen melihat review dari konsumen lainnya dalam melihat gambaran mengenai kualitas maupun pelayanan yang diberikan toko online apabila calon konsumen belum melihat review konsumen merasa kurang percaya diri atas keputusan yang akan diambil. Selain itu calon konsumen yang melihat review positif dari konsumen lainnya, membuat konsumen lebih percaya terhadap produk yang ingin di beli.

Hasil penelitian ini sejalan dengan dua penelitian terdahulu yang dilakukan oleh Althaf Revi Kanitra dan Andriani Kusumawati (2018), menyatakan dalam hasil penelitiannya terdapat pengaruh yang signifikan online customer review terhadap kepercayaan dalam pemebelian produk Oppo Smartphone. Selain itu penelitian yang dilakukan oleh Muhammad Erlandy Haekal, Suharyono, dan Edy yuliyanto menyatakan bahwa electoronic word of mouth atau online customer review menunjukkan pengaruh yang signifikan terhadap kepercayaan. 


\subsection{Pengaruh Online Customer Rating Terhadap Kepercayaan}

Hipotesis yang menyatakan bahwa "online customer rating berpengaruh signifikan terhadap kepercayaan remaja Kota Mataram dalam membeli produk fashion di Shopee" Terbukti. Berdasarkan pengamatan peneliti jumlah rating yang banyak membuat calon konsumen lebih percaya dalam mengambil keputusan dalam membeli produk fashion di Shopee. Sebaliknya apabila jumlah rating dari suatu produk sedikit maka konsumen akan mengurungkan keinginann untk membeli produk tersebut karena merasa tidak yakin terhadap produk fashion yang memiliki jumlah rating yang sedikit. Karena rating merupakan gambaran umum mengenai kualitas produk maupun pelayanan yang diberikan toko online.

Hasil penelitian ini bertentangan dengan penelitian tedahulu yang dilakukan oleh Ahmad Farki, Imam Baihaqi, dan Berto Mulia Wibawa (2016). Hasil yang didapat dari penelitian tersebut adalah OCR baik review maupun rating terbukti memiliki hubungan terhadap minat pembelian pelanggan dan menjadi salah satu fitur yang penting, namun bukan faktor yang menyebabkan meningkatnya kepercayaan pelanggan. diduga disebabkan oleh kepercayaan pada online marketplace ternyata bukan disebabkan oleh review dan rating melainkan faktor lain. Hal ini diduga karena online marketplace merupakan perusahaan yang berskala besar sehingga sudah dipercaya pelanggan, apalagi beberapa online marketplace memiliki garansi apabila berbelanja disana.

\section{Kesimpulan}

Berdasarkan hasil pembahasan maka dapat ditarik kesimpulan sebagai berikut :

1. Online customer review berpengaruh signifikan terhadap kepercayaan remaja Kota Mataram dalam pembelian produk fashion di Shopee. Semakin baik online customer review maka akan meningkatkan kepercayaan remaja Kota Mataram dalam pembelian produk fashion di Shopee.

2. Online customer rating berpengaruh signifikan terhadap kepercayaan remaja Kota Mataram dalam pembelian produk fashion di Shopee. Semakin baik online customer rating maka akan meningkatkan kepercayaan remaja Kota Mataram dalam pembelian produk fashion di Shopee.

\section{Daftar Pustaka}

Arikunto, Suharsimi. 2012. Prosedur Penelitian. Jakarta : Rineka Cipta.

Chou, S.Y., 2012. Online Reviews and Pre-Purchase Cognitive Dissonance : A Theoretical Framework and Research Propositions. Journal of Emerging Trends in Computing and Information Sciences, 3(2), pp.199-204.

Engler, T.H., Winter, P. \& Schulz, M., 2015. Understanding online product ratings: A customer satisfaction model. Journal of Retailing and Consumer Services, 27, pp.113-120.

Farki, Ahmad, Imam Baihaqi, dan Berto Mulia Wibawa." Pengaruh Online Customer Review dan Rating Terhadap Kepercayaan dan Minat Pembelian pada Online Marketplace di Indonesia". JURNAL TEKNIK ITS Vol. 5, No. 2, (2016) ISSN:

2337-3539. Web. 12. Desember. 2018.

Filieri, R., 2014. What makes online reviews helpful? A diagnosticity-adoption framework to explain informational and normative influences in e-WOM. Journal of Business Research, 68(6). 
Ghozali, Imam. 2011. Aplikasi Analisis Multivariate Dengan Program SPSS. Semarang: Universitas Diponegoro.

Guo, G. et al., 2014. Leveraging prior ratings for recommender systems in e-commerce. Electronic Commerce Research and Applications, 13(6), pp.440-455.

Lackermair, G., Kailer, D. \& Kanmaz, K., 2013. Importance of Online Product Reviews from a Consumer' s Perspective. , 1(1), pp.1-5.

Lee, K.T. \& Koo, D.M., 2012. Effects of attribute and valence of e-WOM on message adoption: Moderating roles of subjective knowledge and regulatory focus. Computers in Human Behavior, 28(5), pp.1974-1984.

Pitiyo, Arif. 2014. "78 Persen Pembeli Online Kecewa Pada Produk Belanjaannya", http:/www.google.com/amp/m.merdeka.com/amp/teknologi/78-Persen- PembeliOnline-Kecewa-Pada-Produk-Belanjaannya.html. (diakses tanggal 8 desember 2018).

statistik.kominfo.go.id ( diakses tanggal 8 Januari 2018).

Sugiyono. 2009, Metode Penelitian Kuantitatif, Kualitatif dan RED, Bandung: Alfabeta.

Stanley Lemeshow, David W. Hosmer J, Janeile Klar \& Stephen K. Lwanga, 1997, Besar Sampel dalam Penelitian Kesehatan, Gajah Mada Uneversity Press, Yokyakarta, hal. 2 